\title{
Combining Explicit- Implicit with Focus on Form - Focus on FormS Feedback in EFL Learners' Written Task Accuracy
}

\author{
Asghar Salimi (Corresponding author) \\ Department of English, University of Maragheh, Maragheh, Iran \\ E-mail: Asgharsalimi356@gmail.com \\ Davoud Amini \\ Department of English, Azarbaijan Shahid Madani University, Iran \\ Malahat Yousefzadeh \\ Department of Teaching English as a Foreign Language, Sarab Branch \\ Islamic Azad University, Sarab, Iran \\ E-mail: Yousefzadeh5351@yahoo.com
}

\author{
Received: 23-04- 2015 \\ Accepted: 04-07- 2015 \\ Advance Access Published: August 2015 \\ Published: 01-11- 2015 \\ doi:10.7575/aiac.ijalel.v.4n.6p.113 \\ URL: http://dx.doi.org/10.7575/aiac.ijalel.v.4n.6p.113
}

\begin{abstract}
A number of studies has investigated whether definite types of written corrective feedback combinations of different types are more beneficial than others. It seems that teaching writing and giving feedback to students' written task accuracy is an important task for teachers, so this study tried to investigate the effects of different types of feedback (implicit focus on form, explicit focus on form and explicit focus on forms) on EFL learners' writing. For this purpose, 45 learners of a total number of 90 low intermediate learners studying at Meraj high school in Ardabil were chosen based on their placement test. Initially to make sure that subjects were homogenous, all of them took the Nelson placement test. Results of the test indicated that all of the participation was homogenous. The 45 learners thus were divided into three groups and each of the groups were received feedback through one of the three forms of above mentioned At the end of the treatment, the participants in three groups were given a writing posttest. T-Tests and Oneway ANOVA were used to test the hypotheses. The results of t-tests showed all types of feedback were effective in improving written accuracy and result of Anova (post hoc) showed that there were significant differences between groups and explicit focus on form outperformed than other types of feedback.
\end{abstract}

Keyword: implicit focus on form, explicit focus on form, explicit focus on formS, 12 writing performance at accuracy level

\section{Introduction}

According to Chaudron (1988) corrective feedback is one of the most long-standing efforts of research into teacherstudent interaction with mixed results. There is a debate among the second language teachers about what kind of feedback is effective for L2 learners writing skill. Therefore, due to importance of writing feedback, many studies have been done to investigate different types of it. Despite all researches, there are still no clear way to the giving effective writing feedback. In the literature of language teaching and learning, several studies have been conducted on the effectiveness of various types of writing feedback, for example, explicit versus implicit, Focus on Form (FonF) versus Focus on FormS (FonFS) feedbacks, but there are some kinds of gap in the literature with regard to combinations of the two. Lew (2007) asks this question: How may findings regarding the combined strength of explicit teaching and implicit learning through strong input exposure impact the choice between FonF instruction and a FonFs approach? Therefore, the present study tried to fill the existing gap in the literature and investigate the effects of combining explicit-implicit with FonF-FonFS on EFL learners' written performance in terms of accuracy.

\section{Literature review}

Goldstein (2005 as cited in Long and Doughty 2009, p. 492 ) states intervention at diverse points in a students' writing process approach is one of the main characteristics of the process approach. It seems that teaching writing is an importunate task for teachers and needs considerations because few people write spontaneously and few feel comfortable with a formal writing task (Hamp- Lyons \& Heasley, 1987). Ferris (1997) states that many students do respond to feedback when rewriting their papers. Ryan (1997) believes, feedback provided is effective and can change students about their current writing skills and how the feedback can more develop their writing. 
Explicit and Implicit feedback are two directions of drawing learners' attention to target aspects during task . Long (1996) states Explicit (e.g., grammatical explanation or overt error correction) or implicit (e.g. incidental error correction in a response, e.g. a confirmation check) which reformulates the learners' utterance without interrupting the flow of the conversation - in which case, the negative feedback simultaneously provides additional positive evidenceand perhaps also the absence of the items in the input. (p. 413) During either explicit or implicit instruction, attention may be directed to language forms in isolation, during the processing of meaning, or not at all. These types of attention can be understood as forming a tripartite contrast (focus on form, focus on formS and focus on meaning) (Doughty and Long 2003, p. 265 ).

\subsection{Focus on form and Focus on formS}

Some SLA researchers argue that special attention needs to be paid to form-focused instruction in the case of adult learners since focus on form makes SL development easier (Rahimpour and Salimi, 2010). Doughty (2001) argues that focus on form is differentiated from other approaches in that form-focused instruction engages SL learners shortly and probably at the same time paying attention to form, meaning, and use during a cognitive activity. Focus on formS and focus on form are not polar opposites in the way that form and meaning have often been considered to be. Rather a focus on form involves a focus on formal elements of language, whereas focus on formS is limited to such a focus and focus on meaning keeps out it. Most important, it should be remembered that the fundamental assumption of focuson-form instruction is that meaning and use must already be obvious to the learner at the time that attention is drawn to the linguistic apparatus needed to get the meaning across. (Doughty and Williams, 1998b, p. 4). Ellis (2001) describes focus on form as "any planned or incidental instructional activity that is intended to induce language learners to pay attention to linguistic form" ( pp. 1-2).

\subsection{Recast (implicit focus on form)}

Doughty (2001) mentioned recasts (in this study it was considered as implicit focus on form) have great request as correction strategies because they are minimally intrusive and occur within meaning-focused activities. Bohannon et al. (1996, as cited in Sheen, 2006) describe recast as a kind of correction "that expands, deletes, permutes, or otherwise changes the platform while maintaining overlap in meaning" (p. 434).

\subsection{Consciousness-raising (explicit focus on form)}

Ellis (1994) emphasizes that in consciousness-raising activities (in this study it was considered as explicit focus on form) the learners are not expected to create the target structure, only to understand it by formulating some kind of cognitive representation of how it works. Rutherford (1984) argues that consciousness-raising provides a reasonable way of avoiding many of the pedagogical problems that arise from the teachability hypothesis.

\subsection{Metalinguistic (explicit focus on formS)}

According to Chandler (2003) meta-linguistic corrective feedback ( in this study it was considered as explicit focus on formS) acts as the requirement of the correct form in the student's written texts by underlining the error and writing the target form above it and directing the written corrections at errors in a specific structure. Lyster and Ranta (1997) classify metalinguistic feedback as "comment, information, or question related to the well-formedness of the student's utterance, without explicitly providing the correct form". Ellis (2009) states "Metalinguistic CF involves providing learners with some form of explicit comment about the nature of the errors they have made" (p. 100).

\section{Research}

\subsection{Research questions and hypotheses}

RQ1: Is there any significant difference between pre and post -test in each types of feedback From the points of written accuracy of English past tense?

RQ2: Which type of combination of explicit- implicit feedbacks with focus on form- focus on formS feedback promote L2 written accuracy more?

H1: There are significant differences between pre and post- test in each three types of feedback on EFL written accuracy.

H2: There are significant differences between the effect of different types of combining feedback on EFL learners' written accuracy.

\subsection{Accuracy measure: accuracy performance was calculated as the ratio of correct to incorrect past tense} use. (Fulcher \&Davidson, 2007, p. 8 )

\subsection{Participants}

90 female low intermediate EFL learners with the age range of 13-15 were chosen randomly among classes. As a result of these students' performance in a proficiency test, 45 students were chosen as the target participants. The selected participants were randomly divided in three main groups of 15 students. 
Nelson proficiency test (Fowler and Coe, 1976) was used as a proficiency test in order to assure the homogeneity of the groups. Pre/post tests of writing ability to investigate the learners' improvement after receiving feedback. Some topics for the learners to describe in order to use the past tense forms.

\subsection{Variables of the study}

Independent variable: types of feedback (: implicit focus on form, explicit focus on form, explicit focus on formS).

Dependent variable: written performance at the level of accuracy.

\subsection{Procedure}

As the purpose of this study was to investigate the impact of three types of feedback on L2 learners' written task accuracy in terms of using past tense, students' writing sample was selected as the instrument as for both pretest and posttest. After administering a proficiency test, 45 participants were randomly assigned to three groups implicit focus on form, explicit focus on form and explicit focus on formS. First, participants were asked to complete the pre-test which was a paragraph writing task on a special topic in past tense in order to be sure of their homogeneity and to measure their writing proficiency in use of the target structure. One session later, the treatment (written corrective feedback) was provided. During the course, the participants were assigned to write paragraphs on different topics in past tense. In all three groups the subjects were asked to write the same topic. Students were given 30 minutes to complete their writing and were not given any direction on whether they should focus on accuracy. Then the teacher wrote written feedback for each assignment. In the first group explicit focus on form (recast group) assignments for group were corrected by providing recast. (example: S1: it is wonderful ४ (written recast) oh, it was wonderful.) The second experiment group explicit focus on form ( consciousness raising feedback) teacher highlighted the incorrect verb and wrote their correct forms. The third experimental group explicit focus on formS (metalinguistic feedback ) the part of sentence containing the error was underlined for each sentence then the teacher explained why the sentence is ungrammatical, and wrote it in English in the space provided. In the next sessions, one session after the writing assignment, each written production was given to students for the text revision and given 30 minutes to revise their production. Then, one session after receiving WCF for the last written task, the learners were given another narrative writing test as a post-test. Immediately following a student's error, the researcher corrected them with one of the CF techniques under study.

\section{Data analysis}

The descriptive statistics (the mean scores and standard deviations ) for the three experimental groups are shown in tables 1, 2 and 3. The mean scores of the learners on the post-test are different from each other across the three groups unlike the pre-test mean scores which are very close to each other. To see if the mean difference between the pretest and posttests of writing of each group is significant, three paired t-tests were run.

Table1. means and standard deviation obtained in pre and post test in recast group

\begin{tabular}{lccc}
\hline & $\mathrm{N}$ & Mean & Standard Deviation \\
\hline Pre-test & 15 & $5 / 06$ & $1 / 66$ \\
Post-test & 15 & $6 / 86$ & $1 / 68$ \\
\hline
\end{tabular}

The result of t-test showed that Pre-test is significantly different from post-test, $\mathrm{t}(28)=-2 / 94, \mathrm{p}<0 / 05$.

Table 2. means and standard deviation obtained in pre and post test in consciousness-raising group

\begin{tabular}{llll}
\hline & $\mathrm{N}$ & Mean & Standard Deviation \\
\hline Pre-test & 15 & $5 / 53$ & $2 / 09$ \\
Post-test & 15 & $9 / 2$ & $1 / 79$ \\
\hline
\end{tabular}

The result of t-test showed that Pre-test is significantly different from post-test, $\mathrm{t}(28)=-4 / 97, \mathrm{p}<0 / 05$

Table 3. means and standard deviation obtained in pre and post test in metalinguistic group

\begin{tabular}{lccc}
\hline & $\mathrm{N}$ & Mean & Standard Deviation \\
\hline Pre-test & 15 & $5 / 73$ & $2 / 05$ \\
Post-test & 15 & $7 / 53$ & $2 / 32$ \\
\hline
\end{tabular}

The result of t-test showed that Pre-test is significantly different from post-test $, \mathrm{t}(28)=-2 / 24, \mathrm{p}<0 / 05$. As the above tables show, the mean difference between the pretest and posttests of writing of the all groups is significant at .05 level. The results of t-tests showed all three types of feedback are beneficial for improving written accuracy. Based on the obtained results from the pre-test and post-test, participants in all three groups showed significant change on the post-test. As the table indicates, the explicit focus on form obtained the highest accuracy mean score $(\mathrm{M}=9 / 2)$ followed by the explicit focus on form $\operatorname{group}(\mathrm{m}=7 / 53)$ and the implicit focus on form group had the lowest mean $(\mathrm{M}$ $=6 / 86$ ). Also ,the result of one-way ANOVA is presented in Table 4 showed the differences across the three groups are statistically significant. 
Table 4. The result of One- way ANOVA for three groups

\begin{tabular}{|c|c|c|c|c|}
\hline & SS & df & MS & F \\
\hline Between & 30 & 1 & 30 & 7.5 \\
\cline { 1 - 2 } Within & 112 & 28 & 4 \\
Total & 142 & 29 & \\
\hline R Squared:0.211
\end{tabular}

Adjusted R Squared:0.183

\begin{tabular}{|c|c|c|c|}
\hline F-Statistic & Critical Value & Result & Conclusion \\
\hline 7.5 & 4.1960 & Reject the null hyl & $\begin{array}{l}\text { The compared groups } \\
\text { differ signific antly, } F(1,28) \\
=7.5, p<0.05 .\end{array}$ \\
\hline
\end{tabular}

Just by looking at the mean for each group it is clear that where the differences are the greatest, but this is risky. For this reason, it is necessary to do a post hoc comparison of means. A post-hoc comparison results indicated that the explicit focus on form differed significantly from the explicit focus on formS and the implicit focus on form groups. On the basis of t-tests and Anova results, both of alternative hypotheses were supported. Therefore, each type of feedback had beneficial effect on written accuracy and also providing the three different types of feedback had significantly different effects on written accuracy performance of learners in the use of English past tense.

\section{Conclusion}

Accuracy is one of the important parts for writing skill. The finding of this study is in line with Norris and Ortega (2000) research. Figure 1 shows the result of Norris and Ortega's 2000 study. They found that instruction with explicit focus on form was more effective than explicit focus on forms followed by implicit focus on form over implicit focus on forms.

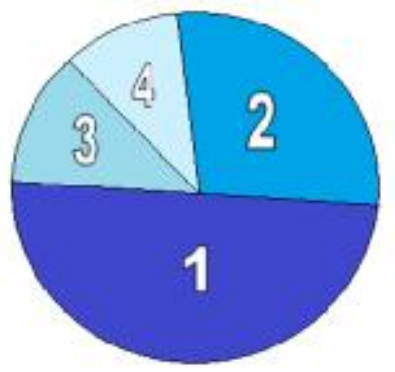

Figure1. Result of Norris and Ortega's 2000 study
1. Focus on form-explicit
2. Focus on formS-explicit
3. Focus on form-implicit 4. Focus on formS-implicit

Table 5. Distribution of pedagogical procedure in the type-of-instruction studies (adapted from Norris and Ortega, 2000)

\begin{tabular}{l|l}
\hline Focus on form & Focus on forms \\
\hline $\begin{array}{l}\text { Implicit (30\% of the instructional types): } \\
18 \% \text { of the instructional types: }\end{array}$ & $\begin{array}{l}11 \% \text { of the instructional types: } \\
\text { corrective models } \\
\text { pre-emptive modeling } \\
\text { Form-experimental }\end{array}$ \\
$\begin{array}{l}\text { Input enhancement } \\
\text { Input flood }\end{array}$ & \\
$\begin{array}{l}\text { Recast } \\
\text { Other implicit }\end{array}$ & \\
$\begin{array}{l}\text { Explicit (70\% of the instructional types): } \\
26 \% \text { of the instructional types: }\end{array}$ & \\
$\begin{array}{l}\text { Compound focus on form } \\
\text { (enhancement }+ \text { feedback) }\end{array}$ & $\begin{array}{l}45 \% \text { of the instructional types: } \\
\text { rule-oriented forms-focused } \\
\text { Consciousness-raising }\end{array}$ \\
$\begin{array}{l}\text { Processing instruction } \\
\text { Metalinguistic task essentialness } \\
\text { (cross-word) }\end{array}$ & $\begin{array}{l}\text { input practice } \\
\text { metalinguistic feedback } \\
\text { output practice } \\
\text { traditional explicit (e.g. rule) }\end{array}$ \\
\hline
\end{tabular}

As table 5 shows, there is a clear advantage for explicit over implicit types of instruction. The result of this study confirms many researchers' findings (Ellis, 2002, 2005; Leow, 1997; Doughty, 1991; Swain and Lapkin, Harley, 1998; 
Robinson, 1997b; Izumi, 2002 ). Also Dabaghi and Basturkmen (2009) mentioned (1) explicit correction make more attention, (2) learners were explicitly corrected on their errors created a contrast with the form in their interlanguage, (3) supplying of the correct form in implicit correction may not have been effective because it was less clear to learners what was wrong with their erroneous utterances and without such understanding, hypothesis modification was not possible, and (4) learners most likely understand the explicit corrections as corrective feedback requiring them to correct their errors whereas this was not the fact with the implicit feedback. On the other hand some researchers' findings are inconsistent with this study and they indicated that there was not any statistically significant differences in the scores of explicit and implicit groups. (Carroll \& Swain,1993; Nagata, 1993; Carroll, 2001; Lyster, 2004; DeKeyser,1993;Kim \& Mathes 2001, Carroll, 2001; Sanz 2003) Saeidi, Zaferanieh and Shatery (2012) studied the effects of focus on form, focus on meaning, and focus on forms on learners' vocabulary learning in ESP context. Their findings reflected that learners in FoF group achieved significantly higher scores than those in FoM and FoFs group. The result of present study showed the recast group (implicit focus on form) had the lowest level performance than other groups, as Lyster (1998) says one problem with recasts is that they can be ambiguous. Some learners may ignore these kinds of feedback or other learners respond to them differently. Also, the result showed consciousness-raising group outperformed than other groups. Ellis (2003) points out that the reasons for the use of consciousness-raising tasks is that explicit knowledge acts as a facilitator for the acquisition of implicit knowledge. Consciousness-raising was supported by Ellis (1994), he says consciousness-raising does not need to involve production by the learner and it isn't against teachability hypothesis because its aim is providing explicit knowledge. Finally it should be noticed that surprisingly Norris and Ortega (2000) concluded that a focus on form and focus on forms are equally effectivell (p. 501). This means that focus on forms approach should not be stigmatized since it has illustrated to be equally beneficial in developing language abilities. For language teachers, the findings of the present study can help them to provide learners with suitable types of feedback in order to help them gain the greatest amount of language proficiency and to response appropriately to the their error. Language teachers and educators need to think about the ways of involving students move fully in the process of using feedback in order to enhance its potential benefit (Hyland, 2010). This study can help to raise teachers' awareness of the different feedback sources and possible way of combining them to make an effective feedback. In addition, the findings of the present study indicates that teachers can combine variety of feedbacks in dealing with their learners' written accuracy. According to Lyster \& Mori (2006) the most successful L2 classroom would be the one in which a variety of feedback types is used and that the combinations of the feedbacks may work better than the isolated feedback.

\subsection{Limitation}

There is always a probability of some weakness and limitation . This study also has certain limitation. In Iran high schools, classes average around 30 students, making it practically impossible for teachers to have constant and regular one-on-one interactions giving students with corrective feedback. Primarily, this study is limited to learners' production of narrative text. It is recommended to study other writing performance such as opinion exchanging , essays, exploration, or description. This study focuses on accuracy of learners' narrative writing and ignores to measure other levels such as complexity and fluency. Another limitation is that as Truscott (2004) pointed out: it is possible that the error correction caused students to write more correct but less complex sentences in an effort to prevent making error. The length of instruction was not very noticable. If the results were gained via a longitudinal study, they could be more trustworthy. Finally teachers shouldn't just consider what type of feedback they give to students, who the students are still also affect feedback types. This point should make with regard to learner's individual differences, their language background and other factors.

\section{References}

Carroll, S. (2001). Input and evidence. The Raw Material of Second Language Acquisition. Amsterdam: John Benjamins.

Carroll, S., \& Swain, M. (1993). Explicit and implicit negative feedback: an empirical study of the learning of linguistic generalizations. Studies in Second Language Acquisition, 15, 357-386.

Chandler, J, (2003). The efficacy of various kinds of error feedback for improvement in the accuracy and fluency of L2 student writing. Journal of Second Language Writing, 12, 267-296.

Chauddron, C. (1988). Second language classrooms: Reacher on teaching and learning. Cambridge: Cambridge University Press.

Dabaghi, A \& Basturkmen, H. (2009). The effectiveness of implicit and explicit error correction on learners' performance. System, 37, 82-98.

Dekeyser, R. (1993). The effect of error correction on L2 grammar knowledge and oral proficiency. Modern Language Journal, 77, 501-51.

Doughty, C. (1991). Second language instruction does make a difference: Evidence from an empirical study on SL relativization. Studies in Second Language Acquisition, 13, 431-469.

Doughty, C. J. (2001). Cognitive underpinnings of focus on form. In P. Robinson (ed.), Cognition and second language instruction (pp.206-55). Cambridge: Cambridge University Press.

Doughty, C. J. \& Long, M. H. (2003). The handbook of Second Language Acquisition. Blackwell Publishing Ltd. 
Doughty, C. J. \& Williams, J. (eds.) (1998). Focus on form in classroom second language acquisition. Cambridge: Cambridge University Press.

Ellis, R. (1994). The study of second language acquisition. Oxford: Oxford University Press.

Ellis, R. (2001). Investigating form-focused instruction. Language Learning, 51(1), 1-46.

Ellis, R. (2002). Does form-focused instruction affect the acquisition of implicit knowledge? A review of the research. Studies in Second Language Acquisition, 24, 223-236.

Ellis, R. (2003). Task-based language learning and teaching. Oxford: OUP.

Ellis, R (Ed.) (2005). Planning and task performance in a second language. Amsterdam: John Benjamins.

Ellis, R. (2009). A typology of written corrective feedback types. ELT Journal, 63(2), 97-107.

Ferris, D. (1997). The influence of teacher commentary on student revision. TESOL Quarterly, 29, 33-53.

Fowler, W.S., and Coe, N. (1976). Nelson English language tests. Thomas Nelson Ltd.

Fulcher,G. \& Davidson, F. (2007). Language Testing and Assessment: an advanced resource book. London: Routledge. Hamp-Lyons, L., \& Heasley, B. (1987). Study writing. Cambridge: Cambridge University Press.

Harley, B. (1998). The role of form-focused tasks in promoting the second language acquisition of children in grade 2. In: Doughty, C., Williams, J. (Eds.), Focus on Form in Classroom Second language Acquisition. Cambridge University Press, Cambridge, pp. 156-174.

Hyland, F. (2010). Future directions in feedback on second language writing: Overview and research agenda. International Journal of English Studies, 10(2), 171-182.

Izumi, S., 2002. Output, input enhancement, and the noticing hypothesis: An experimental study on ESL relativization. Studies in Second Language Acquisition, 24, 541-577.

Kim, H. \& Matches, G. (2001). Explicit vs. Implicit corrective feedback. The korea TESOL Journal, 4, 1-15.

Leow, R. (1997). Attention, awareness, and foreign language behavior. Language Learning, 47(3), 467-505.

Lew , A. w. M. (2007). Pondering over Focus on Form and Focus on FormS: Are There "Equivalent and Large Effects"? Columbia University Working Papers in TESOL \& Applied Linguistics, 7(1), 1-2.

Long, M. (1996). The role of linguistic environment in second language acquisition. In W. C.Ritchie \& B. K. Bahtia (Eds.), Handbook of second language acquisition (pp. 413-468).New York: Academic Press.

Long, M. H. \& Doughty, C. J. (2009).The handbook of Language Teaching. Blackwell Publishing Ltd.

Lyster, R. (1998). Recasts, repetition and ambiguity in 12classroom discourse. Studies in second language Acquisition 20(1), 51-81.

Lyster, R. (2004). Differential effects of prompts and recasts in form-focused instruction. Studies in Second Language Acquisition, 26, 399-432.

Lyster, R., \& Mori, H. (2006). Interactional feedback and interactional counterbalance. Studies in Second Language Acquisition, 28, 209-300.

Lyster, R. \&Ranta, L. (1997). corrective feedback and learner uptake: Negotiation of form in communicative classrooms. Studies in second language Acquisition, 19(1), 37-66.

Nagata, N. (1993). Intelligent computer feedback for second language instruction. Modern Language Journal, 77, 330339.

Norris. J. \& Ortega, N (2000). Effectiveness of L2 instruction: a research synthesis and quantitative meta-analysis. Language Learning, 50(3), 417-528.

Rahimpour M, Salimi A (2010). The impact of explicit instruction on foreign language learners' performance. Procedia- Social and Behavioral Sciences, 2, 1740-1746.

Robinson, P. (1997b). Individual differences and the fundamental similarity of implicit and explicit adult second language learning. Language Learning, 47(1), 45-99.

Rutherford, W. (1984). Language universals and second language acquisition. Amsterdam/Philadelphia: John Benjamin Publishing Company.

Ryan, K. (1997). Lecturer comments and student responses. Directions in Teaching and Learning. 69, 5-13.

Saeidi, M., Zaferanieh, E., \& Shatery, H. (2012). On the Effects of Focus on Form, Focus on Meaning, and Focus on Forms on Learners'Vocabulary Learning in ESP Context. ELT, 5(10), 72-79.

Sanz, C. (2003). Computer delivered implicit vs. explicit feedback in processing instruction. In B. VanPatten (Ed.): Processing Instruction: Theory, Research, and Commentary (pp. 60-99). Mahwah, N.J.: Lawrence Erlbaum.

Sheen, R. (2002). Key concepts in ELT: Focus on from and focus on forms. ELT journal, 56(3),

Sheen, Y. (2006). Exploring the relationship between characteristics of recasts and learner uptake. Language Teaching Research, 10(4), 361-392.

Swain, M., Lapkin, S. (1998). Interaction and second language learning: two adolescent French immersion students working together. The Modern Language Journal, 82(3), 20-337.

Truscott, J. (2004). Evidence and conjecture on the effects of correction: A response to Chandler. Journal of second language writing, 13, 337-47. 